ISSN 1896-8147

DOI: http://dx.doi.org/10.21784/EiZ.2016.016

\title{
Konieczność dodatkowego zabezpieczenia emerytalnego w Polsce
}

\section{Urgency of additional pension insurance in Poland}

\section{Streszczenie:}

W Polsce od wielu lat widać wyraźne kłopoty w zakresie funkcjonowania systemu emerytalnego. Problem ten powoduje przede wszystkim trudna sytuacja demograficzna, która wskazuje na proces starzenia się społeczeństwa oraz niewydolność finansowa głównej instytucji zajmującej się wypłatą świadczeń emerytalnych. Można zatem mówić, że przyszłe świadczenia emerytalne, obarczone są ryzykiem niewypłacalności. W związku z tą sytuacją, należy znaleźć rozwiązanie, które zapewni przyszłym emerytom dostęp do należnych im środków pieniężnych w okresie starości. Jedną z możliwości jest uświadomienie społeczeństwa w zakresie samodzielnego oszczędzania i tworzenia dodatkowego zabezpieczenia emerytalnego. 


\begin{abstract}
:
There are visible problems in functioning of the Poland's pension system for last years. The main factor of this problem is demography, polish society is aging. Moreover, main institution responsible for maintaining and managing pension system is financially insecure. We can say that, the future retirement benefits are at high risk of insolvency. Therefore, there is need to find solution to provide a proper level of income for the future pensioners. One of ideas to solve this problem is to make a society aware of self-saving opportunities for future pension insurance.
\end{abstract}

Słowa kluczowe: demografia, Fundusz Ubezpieczeń Społecznych, adekwatność dochodowa

Keywords: Demography, Social Security Fund, income adequacy

Niniejszy artykuł dotyczy konieczności dodatkowego zabezpieczenia emerytalnego. Jego głównym celem jest wskazanie czynników, które powodują, że takie zabezpieczenie staje się konieczne. Wiąże się to z zaprezentowaniem determinantów mających wpływ na złą sytuację finansową przyszłych emerytów. Celem cząstkowym jest wskazanie możliwości kreowania dodatkowego zabezpieczenia emerytalnego przez osoby prywatne, jak i organizacje, które pozwolą na zwiększenie ilości posiadanych środków w okresie emerytalnym. W celu przybliżenia problematyki związanej z wypłatą przyszłych świadczeń emerytalnych, posłużono się literaturą oraz ogólnodostępnymi artykułami z zakresu finansów i gospodarki. Aby zrealizować postawiony cel, przeanalizowano dane liczbowe zawarte w sprawozdaniach i raportach.

W wyniku przeprowadzonej analizy stwierdzono, że sytuacja finansowa przyszłych emerytów będzie zła. Świadczy o tym przede wszystkim niekorzystna sytuacja demograficzna, w której od lat pojawia się proces starzenia się społeczeństwa, a także zła sytuacja 
finansowa Funduszu Ubezpieczeń Społecznych. Powstaje zatem konieczność dodatkowego zabezpieczenia emerytalnego, które pozwoli na uzupełnienie deficytu, jaki powstanie w budżecie podczas okresu starości.

Problematyka artykułu jest często poruszanym tematem w pracach naukowych, natomiast ma on szczególną wartość $\mathrm{z}$ uwagi na aktualność tego zjawiska.

\section{Wprowadzenie}

Polska od wielu lat zmaga się z problemem w zakresie zabezpieczenia finansowego emerytów. Pomimo przeprowadzenia 1 stycznia 1999 roku reformy emerytalnej i zmiany repartycyjnego charakteru systemu na repartycyjno-kapitałowy, sytuacja finansowa seniorów nadal się pogarsza. Wysokość pobieranych świadczeń wciąż pozostawia wiele do życzenia, a stopa zastąpienia jest niska. Ponadto problematyka systemu emerytalnego dotyka nawet osób aktywnych zawodowo, które martwią się o swoją przyszłość i boją, że nie otrzymają należnej im emerytury.

Cykl życia człowieka składa się z czterech etapów. Dzieciństwa, kształcenia, aktywności zawodowej i starości. Z punktu widzenia systemu emerytalnego, istotne stają się dwa ostatnie etapy, czyli aktywność zawodowa i starość. Wynika to z samych zasad funkcjonowania systemu ubezpieczeń społecznych, którego przymusowy charakter zmusza każdą pracującą osobę do odprowadzania składek. Celem takiego działania jest zabezpieczenie przed negatywnymi skutkami finansowymi na wypadek niezdolności do pracy. W przypadku składki emerytalnej, chroni ona przed utratą środków pieniężnych niezbędnych do życia w chwili utracenia zdolności do pracy w wyniku starości. Dokładniej mówiąc, zapewnia nam ona prawo do świadczeń, które nabyliśmy wcześniej dzięki ograniczeniu konsumpcji w okresie aktywności zawodowej i przekazaniu części środków finansowych w postaci składki. Niestety pomimo zapewnień, że odprowadzana 
składka daje nam prawo do pobierania świadczenia w okresie starości, coraz częściej mówi się o tym, że za jakiś czas wysokość otrzymywanych emerytur będzie niewielka, a być może nie dostaniemy jej wcale.

Sytuacji nie poprawia również trudna sytuacja demograficzna. Od wielu lat w Polsce można zaobserwować tendencję starzejącego się społeczeństwa. Wpływ na to ma niski współczynnik dzietności, który jest daleki od prawidłowej normy. Do tendencji starzenia się społeczeństwa przyczynia się również fakt, że ludzie żyją coraz dłużej. Wydłużający się wiek życia wpływa na okres pobierania świadczenia emerytalnego generując dodatkowe zapotrzebowanie na kapitał.

Istnieje jeszcze szereg innych determinantów, które rodzą obawę o sytuację finansową obecnych i przyszłych emerytów. Wszystkie jednak składają się na spójny obraz, ukazując ogrom problemu, z jakim od lat zmaga się Polska i uświadamiając, że konieczne jest dodatkowe zabezpieczenie finansowe. Powstaje zatem pytanie, co robić, aby po przejściu na emeryturę nie martwić się o swoją sytuację materialną i żyć na dotychczasowym poziomie.

\section{Demografia}

Od wielu lat w Polsce obserwujemy proces starzenia się społeczeństwa. Wpływ na to mają przede wszystkim dwa czynniki, do których należy dzietność oraz wydłużająca się długość życia. Dodatkowy czynnik, który niekorzystnie wpływa na demografię w Polsce, stanowią liczne emigracje osób aktywnych zawodowo. Wszystkie te determinanty wpływają negatywnie na funkcjonowanie systemu emerytalnego i generują obawy o jego dalsze istnienie. Demografia ma znaczący wpływ na konieczność dodatkowego zabezpieczenia emerytalnego, dzięki któremu nasz poziom życia po przejściu na emeryturę nie ulegnie załamaniu. 
Wykres 1. Współczynnik dzietności w Polsce w latach 1990-2015

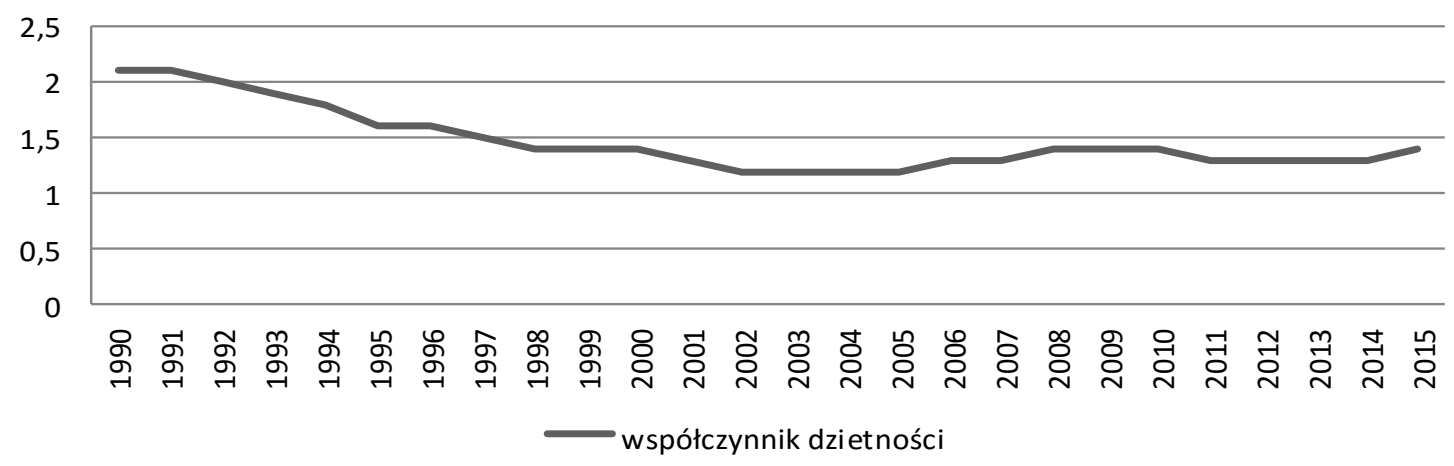

Źródło: opracowanie własne na podstawie danych zawartych na stronie internetowej http://www.rynekpracy.pl/monitor_rynku_pracy_1.php/wpis.222.

Na wykresie 1 zobrazowano współczynnik dzietności w Polsce w latach 1990-1015. Jego niski poziom powoduje brak zdolności do odtwarzania rodzin na poziomie, który zapewni prostą zastępowalność pokoleń. Najprościej ujmując, nasza populacja się kurczy. Biorąc zatem pod uwagę sposób działania systemu emerytalnego, którego środki finansowe pochodzą z odprowadzanych składek emerytalnych przez osoby aktywne zawodowo, można wywnioskować, że wpływy te są coraz mniejsze. Odwrotnie dzieje się z wydatkami, które wzrastają wraz ze wzrostem liczby osób w wieku poprodukcyjnym. Prawidłowa wartość współczynnika dzietności, która pozwala na odtworzenie pokolenia wynosi 2,1. W Polsce w roku 2015 wartość współczynnika wyniosła 1,4. Państwo próbuje walczyć z tym problem. Jednym z działań mających na celu poprawienie współczynnika dzietności było uruchomienie programu 500+. Jego podstawowym celem była zachęta do poszerzania swojej rodziny. Niestety, według przeprowadzonych prognoz, program ten przyczyni się do poprawy tego współczynnika tylko w niewielkim stopniu, bo wzrośnie on zaledwie 
do poziomu 1,6. Warto również wspomnieć, że w roku 2011 na 27 państw Unii Europejskiej, polski wskaźnik dzietności uplasował się na miejscu 25. Niższy wynik odnotowała jedynie Rumunia oraz Węgry ${ }^{45}$.

Wykres 2. Średni wiek życia mężczyzn i kobiet- dotychczasowy i prognozowany

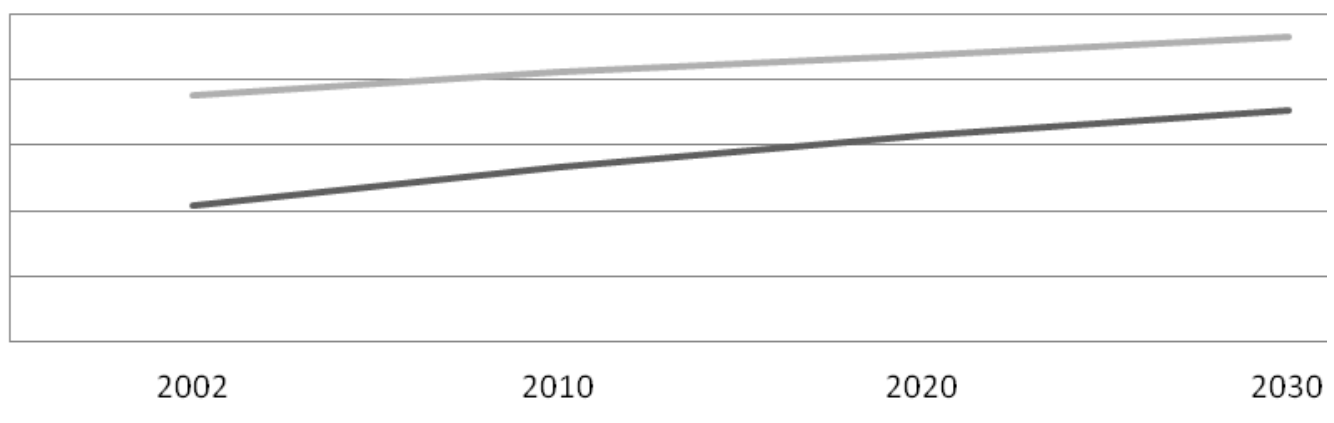

—Średni wiek mężczyzny —Średni wiek kobiety

Źródło: Opracowanie własne na podstawie danych zawartych na stronie internetowej http://www.clf.net.pl/15-demografia-polski.

Na wykresie 2 przedstawiono dotychczasowy oraz prognozowany średni wiek życia mężczyzn oraz kobiet. Wiek obu płci charakteryzuje się silną tendencją wzrostową. Oznacza to, że zarówno mężczyźni, jak i kobiety, będą żyć coraz dłużej. W roku 2030 średni wiek mężczyzn osiągnie wartość 77,6 , a kobiet 83,3. Przekładając to na wypłatę emerytur, można zauważyć poważny problem. Wydłużający się okres życia powoduje wydłużenie czasu pobierania świadczenia emerytalnego, co może generować problem z pozyskaniem środków na ten cel.

45 Rynek pracy, http://www.rynekpracy.pl/monitor_rynku_pracy_1.php/wpis.222 (17.01.2017) 
Spowoduje to dodatkowe obciążenie nie tylko dla budżetu państwa, ale i dla osób pozostających w aktywności zawodowej ${ }^{46}$.

\section{Sytuacja finansowa Funduszu Ubezpieczeń Społecz- nych}

Na konieczność dodatkowego zabezpieczenia emerytalnego, wpływ ma nie tylko sytuacja demograficzna, ale i sytuacja Funduszu Ubezpieczeń Społecznych. Rolą Funduszu jest gromadzenie składek od osób aktywnych zawodowo oraz ich wyplata w postaci świadczeń na rzecz osób, którym to świadczenie przysługuje. Można jednak zaobserwować poważny problem, jakim przede wszystkim jest nierównomierność wydatków oraz wpływów ze składek.

Wykres 3. Wpływy ze składek i wydatki Funduszu Ubezpieczeń Społecznych w latach 2007-2015

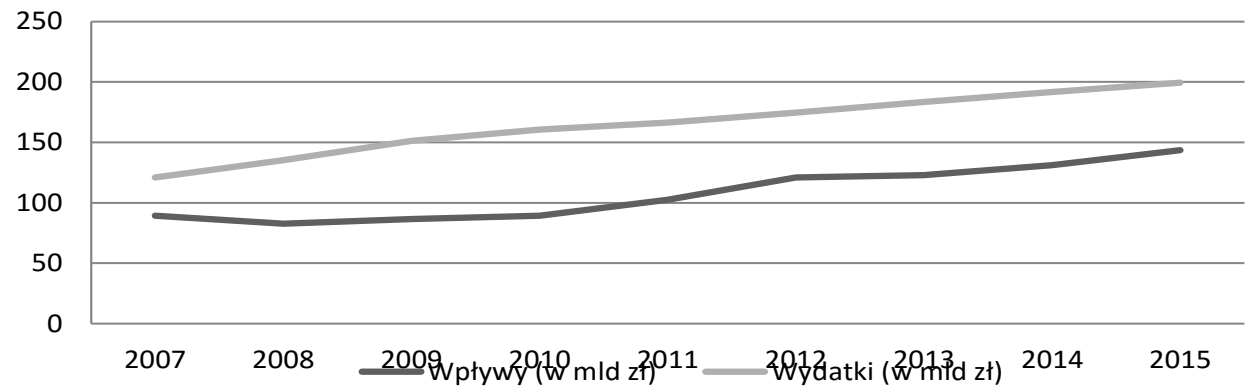

Źródło: Opracowanie własne na podstawie danych zawartych na stronie internetowej http://www.bs.net.pl/analitycy-banku-bps-sa/deficyt-ubezpieczen-spolecznych.

\footnotetext{
${ }^{46}$ D. Graniewska, Warunki życia emerytów i rencistów w Polsce i $w$ krajach zachodnich, Warszawa 1999, s. 37.
} 
Na wykresie 3 przedstawiono poziom wpływów Funduszu Ubezpieczeń Społecznych pochodzących ze składek oraz wydatki, które stanowią wypłacane świadczenia. $\mathrm{Z}$ łatwością można zauważyć, że wydatki są duże większe niż wpływy. Oznacza to, że Fundusz Ubezpieczeń Społecznych od lat generuje deficyt. Może to powodować zmniejszenie wartości wypłacanych świadczeń, a w dalszej przyszłości upadek Funduszu. Ten czarny scenariusz spowodowałby znaczne obniżenie poziomu konsumpcji, a w najgorszym wariancie całkowitą utratę świadczenia emerytalnego. Generuje to konieczność dodatkowego zabezpieczania finansowego na wypadek starości we własnym zakresie.

Wykres 4. Środki pieniężne przekazane z budżetu państwa do Funduszu Ubezpieczeń Społecznych (wartości dotychczasowe i prognozowane)

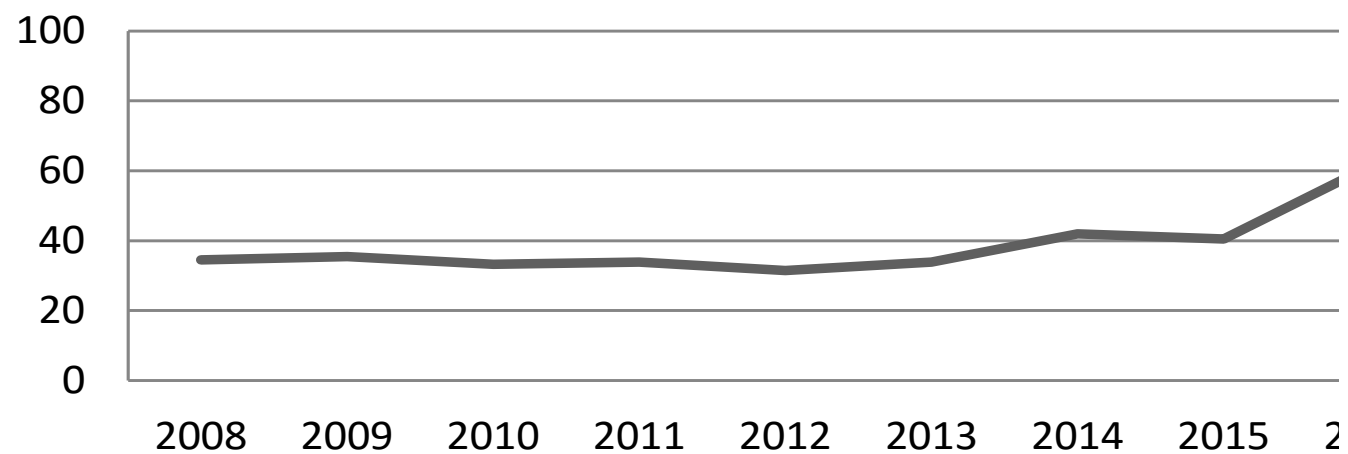

Źródło: Opracowanie własne na podstawie danych zawartych na stronie internetowej

http://www.money.pl/emerytury/raporty/artykul/dziura;w;zus;rosnie;coraz;trudni ej;bedzie;ja;zasypac,139,0,519563.html

Na wykresie 4 zobrazowano jeden ze sposobów eliminowania deficytu powstającego corocznie w Funduszu Ubezpieczeń Społecz- 
nych, którego główną gałąź stanowi Fundusz Emerytalny. Państwo ze swojego budżetu dokłada corocznie ok. 40 mld złotych. W roku 2015 dofinansowanie wyniosło 40,5 mld złotych. W związku z obniżeniem wieku emerytalnego, które ma miejsce w roku 2017, ZUS przygotował prognozy deficytu i symulację finansowania ubezpieczeń społecznych z budżetu państwa. Wynika z niej, że w roku 2020 w Funduszu Ubezpieczeń Społecznych zabraknie kwoty ponad 60 mld złotych ${ }^{47}$. Patrząc $\mathrm{z}$ tej perspektywy można zauważyć, że Fundusz ten, będzie znajdował się w coraz cięższej sytuacji finansowej. W dłuższym okresie, kiedy poziom obciążenia budżetu państwa z tytułu emerytur stanie się dla niego zbyt wysoki, może to doprowadzić do jego upadku.

Istotną rolę odgrywa również Fundusz Rezerwy Demograficznej powstały w 2002 roku w celu wspomagania procesu wypłat świadczeń emerytalnych po roku 2020. Mimo pierwotnych założeń, pieniądze z tego Funduszu wspomogły wypłatę emerytur już w roku 2010 w kwocie 7,5 mld złotych. W roku 2015 stan Funduszu Rezerwy Demograficznej wyniósł 19,8 mld złotych, podczas gdy według pierwotnych założeń w roku 2020 miał on wynosić 200 mld złotych ${ }^{48}$. Uzyskanie takiego wyniku w ciągu 5 lat nie jest możliwe, co oznacza, że funkcjonowanie takiego Funduszu, nie zapewni bezpieczeństwa w zakresie wypłaty świadczeń. Stanowi to kolejny powód do samodzielnego oszczędzania i konieczności zabezpieczenia na wypadek starości.

\footnotetext{
47 Bankier, http://www.bankier.pl/wiadomosc/Wysoka-cena-za-obnizenie-wiekuemerytalnego-3639226.html (16.01.2017)

48 Money, http://www.money.pl/gospodarka/wiadomosci/artykul/funduszrezerwy- demograficznej-przejmie,25,0,2117145.html (16.01.2017)
} 


\section{Adekwatność dochodowa systemu emerytalnego}

Jednym z mierników, który pozwala ocenić poprawność funkcjonowania systemu emerytalnego jest adekwatność dochodowa. Służy ona przede wszystkim ${ }^{49}$ :

- określeniu, czy system emerytalny zapewnia emerytom dochód, który chroni ich przed ubóstwem,

- porównaniu wielkości konsumpcji z okresu aktywności zawodowej oraz tej, która pojawia się w okresie emerytalnym,

- $\quad$ sprawdzeniu, czy między kobietami a mężczyznami, występują niepożądane dysproporcje dotyczące dwóch wyżej wymienionych punktów.

Jednym ze wskaźników, który pozwala określić, czy system emerytalny zapewnia dochód chroniący przed ubóstwem, jest wskaźnik pogłębionej deprywacji materialnej. Miernik ten jest o tyle ciekawy, że pozwala określić odsetek populacji, który nie może pozwolić sobie na zaspokojenie przynajmniej $4 \mathrm{z} 9$ potrzeb50:

- opłacanie rachunków lub czynszu,

- utrzymanie odpowiedniej temperatury w domu,

- możliwość pokrycia niespodziewanych wydatków,

- jedzenie mięsa lub ryb co drugi dzień,

- możliwość spędzenia tygodniowych wakacji poza domem,

- posiadanie samochodu,

- posiadanie pralki,

- posiadanie kolorowego telewizora,

- posiadanie telefonu.

Warto zauważyć, że wymienione wyżej potrzeby są tak naprawdę podstawowymi rzeczami, jakie każdy człowiek powinien mieć. Nie są

\footnotetext{
49 F. Chybalski [w:] F. Chybalski (red.), Adekwatność dochodowa, efektywność $i$ redystrybucja w systemach emerytalnych, Wydawnictwo C.H. Beck, Warszawa, 2016, s. 24-25.

50 op. cit., s. 28.
} 
to wygórowane pragnienia, lecz oczekiwania i przedmioty użytku codziennego.

Wykres 5. Wartość wskaźnika pogłębionej deprywacji materialnej w Polsce w 2013 roku na tle wybranych państw

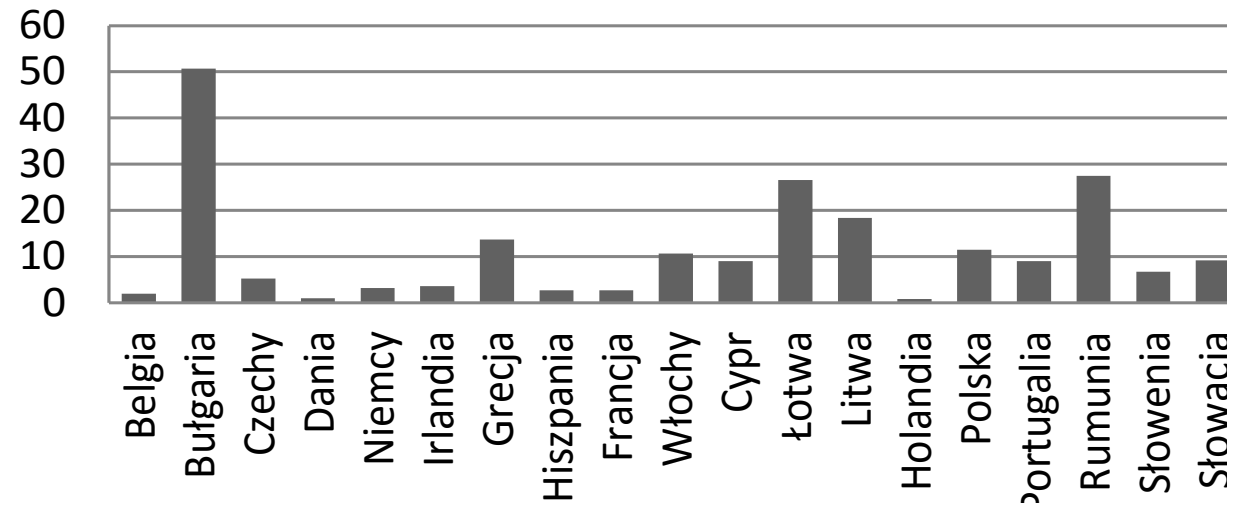

Źródło: Opracowanie własne na podstawie F. Chybalski [w:] F. Chybalski (red.), Adekwatność dochodowa, efektywność i redystrybucja $w$ systemach emerytalnych, Wydawnictwo C.H. Beck, Warszawa, 2016, s. 82-83.

Na wykresie 5 przedstawiono wartość pogłębionej deprywacji materialnej, jaka miała miejsce $\mathrm{w}$ Polsce oraz w wybranych państwach w 2013 roku. Polska uplasowała się z wynikiem 11,5. Porównując ją do innych państw, można zauważyć, że jest to wysoki poziom. Wyżej znajduje się tylko Bułgaria, Grecja, Łotwa, Litwa oraz Rumunia. Wartość wskaźnika wśród pozostałych państw jest dużo niższa, zatem można stwierdzić, że w Polsce problem zaspokojenia podstawowych potrzeb materialnych jest duży. 
Wykres 6. Wartość wskaźnika stopy zastąpienia w latach 2005-2013

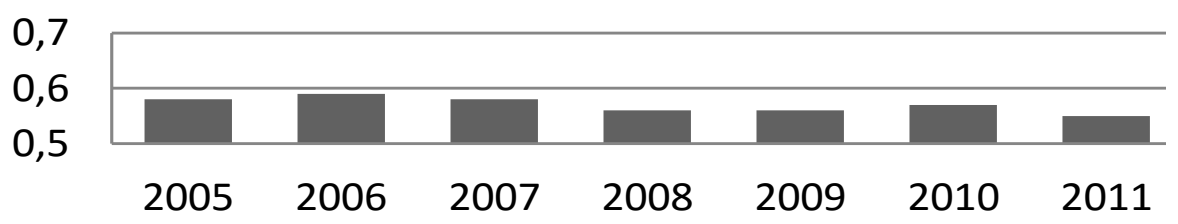

Źródło: Opracowanie własne na podstawie F. Chybalski [w:] F. Chybalski (red.), Adekwatność dochodowa, efektywność i redystrybucja $w$ systemach emerytalnych, Wydawnictwo C.H. Beck, Warszawa, 2016, s. 83.

Porównując wielkość konsumpcji z okresu aktywności zawodowej i okresu emerytalnego, należy zwrócić uwagę na stopę zastąpienia. Jej wielkość wskazuje, w jakim stopniu wartość otrzymywanej emerytury odpowiada wartości dochodu otrzymywanego w czasie aktywności zawodowej. W przypadku Polski stopa zastąpienia kształtuje się na poziomie bliskim lub równym 60\%. Oznacza to, że przeciętny emeryt otrzymuje świadczenie w wysokości $60 \%$ dochodu, który otrzymywał przed zakończeniem aktywności zawodowej. Oczywiście najbardziej pożądaną wielkością jest $100 \%$, ponieważ oznaczałoby to, że poziom naszego życia i wielkość konsumpcji nie ulegną zmianie.

\section{Przykładowe formy dodatkowego zabezpieczenia emerytalnego}

$\mathrm{W}$ związku $\mathrm{z}$ problemami $\mathrm{w}$ zakresie funkcjonowania systemu emerytalnego oraz trudnej sytuacji demograficznej Polski, powstaje konieczność samodzielnego zabezpieczenia emerytalnego. Jeżeli zawiódł system stworzony przez państwo, najlepszym rozwiązaniem staje się samodzielne oszczędzanie i inwestowanie na poczet przyszłej emerytury. Dla części osób jednym ze sposobów zabezpieczenia emerytalnego może być inwestowanie w rodzinę, a dokładniej ujmu- 
jąc, w potomstwo. Brzmi kontrowersyjnie, jednak posiadanie dzieci może stanowić formę inwestycji, która zwróci się w okresie starości. Pracujące dzieci będą mogły wesprzeć finansowo swoich emerytowanych rodziców, tym samym odwdzięczając się za trud i środki włożone w edukację, wychowanie, czy zapewnienie wszystkich potrzeb. Istnieje jednak ryzyko, że sytuacja finansowa dzieci nie będzie na tyle dobra, by mogły one pomóc materialnie swoim rodzicielom. Dlatego warto spojrzeć na inne możliwości, które pozwolą na utrzymanie dotychczasowego poziomu życia w okresie starości.

Jedną z możliwości samodzielnego finansowania jest III filar. Stanowi on formę dobrowolnego ubezpieczenia emerytalnego, a wypłaty $\mathrm{z}$ tego filaru są uzupełnieniem świadczeń otrzymywanych w ramach funkcjonowania pozostałych dwóch, czyli ZUS i OFE. W skład tego filaru wchodzi Indywidualne Konto Emerytalne (IKE), Indywidualne Konto Zabezpieczenia Emerytalnego (IKZE) oraz Pracownicze Programy Emerytalne (PPE) ${ }^{51}$. Niestety jest on nadal mało popularny, więc środki zgromadzone na tym filarze nie są w stanie w zasadniczy sposób zwiększyć przyszłych emerytur ${ }^{52}$. Posiadanie Indywidualnego Konta Emerytalnego lub Indywidualnego Konta Zabezpieczenia Emerytalnego jest związane z podpisaniem umowy o prowadzenie IKE lub IKZE z funduszem inwestycyjnym, instytucją prowadzącą działalność maklerską, bankiem, zakładem ubezpieczeń na życie itp. ${ }^{53}$ Natomiast Pracownicze Programy Emerytalne są pewnego rodzaju grupowym oszczędzaniem na emeryturę z inicjatywy pracodawcy. To on odprowadza składkę na ten cel, natomiast pracownik może zadeklarować składkę dodatkową potrącaną od jego wynagrodzenia. Środki trafiają

\footnotetext{
51 J. Wantoch- Rekowski [w:] J, Wantoch- Rekowski (red.), Podstawy prawa finansów ubezpieczeń społecznych, Wydawnictwo Dom Organizatora, Toruń, 2015, s. 39-40.

52 Emerytura gov, http://emerytura.gov.pl/iii-filar/statystyka/ (16.01.2017)

53Emerytura gov, http://emerytura.gov.pl/iii-filar/indywidualne-konto-emerytalne/ (16.01.2017)
} 
do instytucji finansowej wybranej przez pracodawcę w porozumieniu z pracownikami i tam podlegają odpowiedniemu zarządzaniu.

Wykres 7. Liczba kont IKE, IKZE, PPE na koniec roku 2013

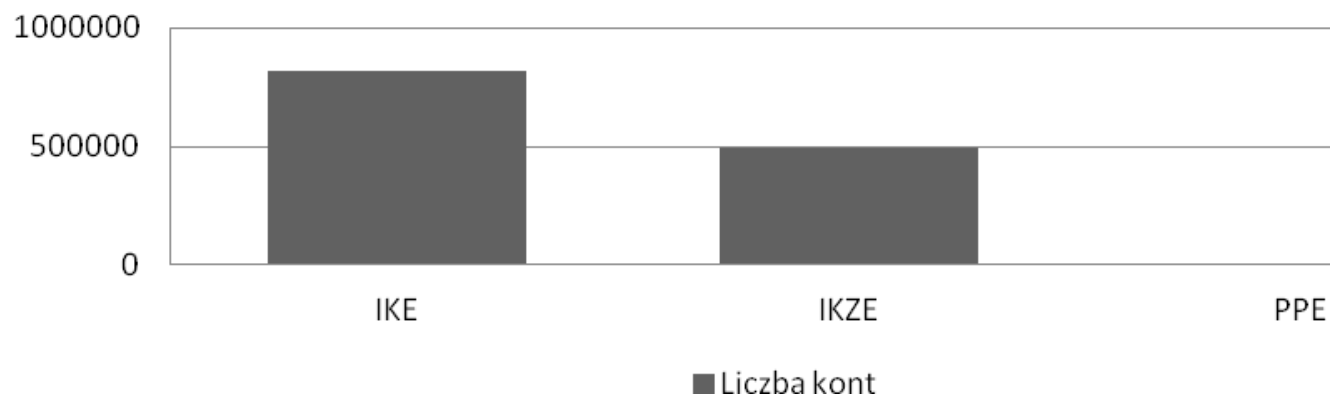

Źródło: Opracowanie własne na podstawie danych zawartych na stronie internetowej http://emerytura.gov.pl/iii-filar/statystyka/

Na wykresie 7 przedstawiono liczbę kont IKE, IKZE i PPE na koniec 2013 roku. Największą popularnością cieszy się Indywidualne Konto Emerytalne, jednak i tak liczba tych kont wynosi ledwo ponad 800 tysięcy. Jest to bardzo niewielka wartość patrząc na liczbę osób aktywnych zawodowo. 
Wykres 8. Wartość środków w IKE, IKZE, PPE na koniec 2013 roku

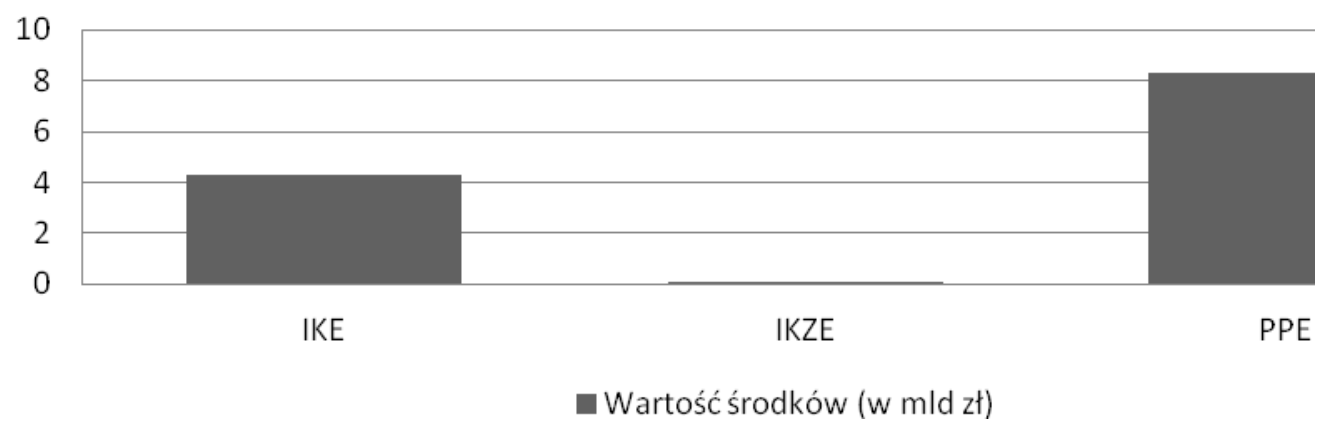

Źródło: Opracowanie własne na podstawie danych zawartych na stronie internetowej http://emerytura.gov.pl/iii-filar/statystyka/

Na wykresie 8 zobrazowano wartość środków pieniężnych (w mld zł) zawartych w IKE, IKZE i PPE. Można zauważyć, że mimo niewielkiej ilości kont Pracowniczych Programów Emerytalnych, mają one największą wartość. Niestety kwoty w IKE, IKZE i PPE są nadal niewielkie. Wartość środków na koniec 2013 roku w PPE wynosiła nieco ponad 8 mld złotych, podczas gdy samo dofinansowanie deficytu FUS z budżetu państwa sięgało wymiaru blisko 40 mld złotych. Warto więc pomyśleć nad edukacją społeczeństwa w zakresie korzystania z III filaru lub upowszechnić istnienie Pracowniczych Programów Emerytalnych, które gromadzą największe kwoty. Formą, która spowodowałaby znaczne zainteresowanie i wzrost środków gromadzonych w III filarze, jest zwiększenie udziału przedsiębiorstw w finansowaniu tego filaru. Taką możliwość dają tzw. systemy kafeteryjne. Stanowią one nie tylko pozafinansowy motywator dla pracowników, ale i szansę na zwiększenie zabezpieczenia emerytalnego. Systemy kafeteryjne umożliwiają pracownikom dokonanie wyboru pomiędzy oferowanymi przez pracodawcę benefitami. Dzięki temu wzrasta atrakcyjność wynagrodzenia pracownika, które w tym przypadku wzbogaca się o elementy pozafinansowe. $\mathrm{W}$ przypadku emerytury, pracodawcy mogą 
dać pracownikom możliwość skorzystania z programów emerytalnych w ramach przyznanego im benefitu. Jest to niejako forma premii, która motywuje pracowników do lepszej pracy, powoduje wzrost zadowolenia i satysfakcji oraz może korzystnie wpłynąć na ilość absencji. W tym przypadku korzyścią byłoby również dodatkowe zabezpieczenie emerytalne, z którego pracownicy będą mogli skorzystać w okresie starości. Obecnie niewiele firm korzysta z systemów kafeteryjnych, ponieważ wiąże się to z wysokimi kosztami, a w przypadku programów emerytalnych, z długim okresem trwania. Warto więc uświadomić pracodawców, że takie rozwiązanie jest bardzo silnym motywatorem, a stworzenie benefitu dającego możliwość zabezpieczenia emerytalnego jest w obecnym czasie bardzo pożądane ${ }^{54}$.

Inną formą zabezpieczenia emerytalnego mogą być posiadane nieruchomości. Poza możliwością ich sprzedaży lub wynajmu podczas okresu starości, stanowią one dodatkowe źródło pozyskania kapitału chociażby poprzez skorzystanie z odwróconej hipoteki. Jest to produkt, który od grudnia 2014 roku został wprowadzony do Polski dzięki podpisaniu Ustawy o Odwróconym Kredycie Hipotecznym, jednak mimo upływu lat, żaden bank nie wprowadził jej do swojej oferty. Odwrócona hipoteka jest źródłem pozyskania dodatkowego kapitału dla emerytów. Polega na zawarciu umowy między bankiem a emerytem, który to zobowiązuje się do przekazania, po swojej śmierci, prawa własności posiadanej nieruchomości bankowi. Wówczas to bank staje się właścicielem nieruchomości. W zamian wypłaca on emerytowi miesięczne transze w wysokości uzgodnionej na podstawie wyceny wartości nieruchomości oraz wieku emeryta. Środki te stanowią dodatkowy dochód na emeryturze ${ }^{55}$. Pomimo wejścia

\footnotetext{
54 HR trendy, http://www.hrtrendy.pl/2008/01/19/wynagrodzenia-kafeteryjnekrok-po-kroku/ (20.03.2017)

55 E. Poprawska., P. Kowalczyk, Hipoteka odwrócona (reverse mortgage), [w:] A Szelądowska (red.), Współczesna bankowość hipoteczna, CeDeWu, Warszawa 2010, s.86.
} 
w życie ustawy regulującej funkcjonowanie tego produktu na polskim rynku finansowym, nadal nie ma go w ofercie żadnego z banków. Głównym powodem jest niechęć emerytów argumentowana brakiem zaufania do banków, chęcią przekazania nieruchomości rodzinie $w$ formie spadku, nieznajomością tego produktu oraz posiadaniem wystarczającej ilości środków pieniężnych na podstawowe potrzeby, jakimi są czynsz, żywność oraz leki ${ }^{56}$. Odwrócona hipoteka mogłaby w pewnym stopniu wspomóc sytuację finansową emerytów, tym bardziej, że aktualna stopa zastąpienia wynosi $60 \%$. Aby utrzymać poziom życia na dotychczasowym poziomie, należałoby pozyskać kapitał z dodatkowych źródeł, chociażby takich jak odwrócony kredyt hipoteczny. W opinii ekspertów polski rynek hipoteczny jest wciąż mało dojrzały, lecz istnieje duże prawdopodobieństwo jego rozwoju oraz wprowadzenia nowych produktów, m.in. odwróconego kredytu hipotecznego ${ }^{57}$. Wówczas posiadania nieruchomość stałaby się formą dodatkowego zabezpieczenia emerytalnego na wypadek uzyskania niskiego świadczenia emerytalnego lub nieotrzymania go wcale.

\section{Uwagi końcowe}

Obecna sytuacja systemu emerytalnego jest zła, a przeprowadzane prognozy nie przewidują poprawy. Przeciwnie, możemy spodziewać się pogorszenia. Negatywny wpływ ma również sytuacja demograficzna. Rodzi to konieczność dodatkowego zabezpieczenia emerytalnego. Jedyną sytuacją, która mogłaby uchronić nas przed koniecznością samodzielnego zabezpieczenia i martwienia się o przyszłą emeryturę, byłyby działania podjęte przez państwo. Reforma z 1 stycznia 1999 roku nie przyniosła pożądanego efektu. W chwili obecnej występuje konieczność ponownego zreformowania systemu. Państwo powinno zacząć pracować nad rozwiązaniami, które poprawiłyby

\footnotetext{
56 Badania własne przeprowadzone w kwietniu 2016 roku na grupie 100 emerytów. 57 G. Główka, Mieszkaniowy kredyt hipoteczny w Polsce, Szkoła Główna Handlowa w Warszawie - Oficyna Wydawnicza, Warszawa 2010, s. 50.
} 
funkcjonowanie systemu emerytalnego i sytuację finansową przyszłych emerytów. Być może jednym z słusznych rozwiązań, choć dość radykalnych, byłaby likwidacja obecnego systemu emerytalnego. Należałoby wtedy przeprowadzić edukację społeczeństwa w zakresie samodzielnego oszczędzania i wymusić, aby zaczęło ono oszczędzać na swoją emeryturę we własnym zakresie, co w chwili obecnej robi niewiele osób. Społeczeństwo nie jest świadome ogromu problemu emerytalnego oraz nie posiada wystarczającej wiedzy, która pozwoliłaby mu na samodzielne oszczędzanie.

Jeżeli państwo nie podejmie skutecznych działań naprawczych $\mathrm{w}$ zakresie systemu emerytalnego, Polskę czeka emerytalna katastrofa. Dlatego już teraz osoby młode, powinny myśleć nad dodatkowym zabezpieczeniem, które uchroni je przed negatywnymi skutkami starości, a więc utratą dochodu. Zawsze istnieje też inne, dość kontrowersyjne rozwiązanie, czyli przeprowadzka do Danii, Holandii, Szwecji lub Finlandii, których system emerytalny oceniany jest, jako efektywny i stabilny. Wówczas zmartwienia o niepewnej przyszłości i poziomie życia w czasie dezaktywacji zawodowej skończyłyby swój byt.

\section{Literatura}

1. Chybalski F. (red.), Adekwatność dochodowa, efektywność i redystrybucja w systemach emerytalnych, Wydawnictwo C.H. Beck, Warszawa, 2016.

2. Główka G., Mieszkaniowy kredyt hipoteczny w Polsce, Szkoła Główna Handlowa w Warszawie - Oficyna Wydawnicza, Warszawa 2010.

3. Graniewska D., Warunki życia emerytów i rencistów w Polsce i w krajach zachodnich, Warszawa 1999.

4. A Szelądowska (red.), Współczesna bankowość hipoteczna, CeDeWu, Warszawa 2010.

5. Wantoch- Rekowski J. (red.), Podstawy prawa finansów ubezpieczeń społecznych, Wydawnictwo Dom Organizatora, Toruń, 2015. 


\section{Źródła internetowe}

1. Bankier, http://www.bankier.pl/wiadomosc/Wysoka-cena-zaobnizenie-wieku-emerytalnego-3639226.html (16.01.2017).

2. BS NET, http://www.bs.net.pl/analitycy-banku-bps-sa/deficytubezpieczen-spolecznych. (16.01.2017.)

3. CLF, http://www.clf.net.pl/15-demografia-polski. (16.01.2017).

4. Emerytura gov, http://emerytura.gov.pl/iii-filar/statystyka/ (16.01.2017).

5. HR trendy, http://www.hrtrendy.pl/2008/01/19/wynagrodzeniakafeteryjne-krok-po-kroku/ (20.03.2017).

6. Money,

http://www.money.pl/emerytury/raporty/artykul/dziura;w;zus;rosnie; coraz;trudniej;bedzie;ja;zasypac,139,0,519563.html (17.01.2017).

7. Money, http://www.money.pl/gospodarka/wiadomosci/artykul/funduszrezerwy-demograficznej-przejmie,25,0,2117145.html (16.01.2017).

8. Rynek pracy, http://www.rynekpracy.pl/monitor_rynku_pracy_1.php/ wpis.222. (17.01.2017). 